\title{
Het management van de kennisstroom: een sleutelrol voor het personeelsbeleid
}

Citation for published version (APA):

den Hertog, J. F., \& van Sluijs, E. (1995). Het management van de kennisstroom: een sleutelrol voor het personeelsbeleid. MERIT, Maastricht Economic Research Institute on Innovation and Technology. MERIT Research Memoranda No. 004 https://doi.org/10.26481/umamer.1995004

Document status and date:

Published: 01/01/1995

DOI:

10.26481/umamer.1995004

Document Version:

Publisher's PDF, also known as Version of record

\section{Please check the document version of this publication:}

- A submitted manuscript is the version of the article upon submission and before peer-review. There can be important differences between the submitted version and the official published version of record.

People interested in the research are advised to contact the author for the final version of the publication, or visit the DOI to the publisher's website.

- The final author version and the galley proof are versions of the publication after peer review.

- The final published version features the final layout of the paper including the volume, issue and page numbers.

Link to publication

\footnotetext{
General rights rights.

- You may freely distribute the URL identifying the publication in the public portal. please follow below link for the End User Agreement:

www.umlib.nl/taverne-license

Take down policy

If you believe that this document breaches copyright please contact us at:

repository@maastrichtuniversity.nl

providing details and we will investigate your claim.
}

Copyright and moral rights for the publications made accessible in the public portal are retained by the authors and/or other copyright owners and it is a condition of accessing publications that users recognise and abide by the legal requirements associated with these

- Users may download and print one copy of any publication from the public portal for the purpose of private study or research.

- You may not further distribute the material or use it for any profit-making activity or commercial gain

If the publication is distributed under the terms of Article $25 \mathrm{fa}$ of the Dutch Copyright Act, indicated by the "Taverne" license above, 


\title{
Het management van de kennisstroom: Een sleutelrol voor het personeelsbeleid
}

\author{
J.Friso den Hertog $\mathcal{E}$ Ed van Sluijs
}

(MERIT)

\section{Voorwoord}

Vernieuwingen in de organisatiewetenschappen komen vooral voort uit de praktijk. Daarmee onderscheidt organisatie-onderzoek en organisatie-advisering zich niet van veel andere vormen van dienstverlening. Dit geldt in het bijzonder voor deze studie. De betrokkenheid bij adviesprojecten heeft de onderzoekers op het spoor van het kennismanagement gezet. Een opdracht van de Europese Unie (DG-V) heeft de mogelijkheden geboden de ervaringen van een vijftal bedrijven te analyseren, te vergelijken en te rapporteren. Wij zijn Lars Erik Andreasen zeer erkentelijk voor de actieve steun bij deze studie. Daarnaast kon in de studie worden geprofiteerd van de onderzoekervaringen die zijn opgedaan in het programma "HRM in onderzoekinstellingen". Onze dank gaat natuurlijk evenzeer uit naar de bedrijven die voor ons de deur hebben geopend en de managers met wie wij zo diep op hun ervaringen hebben kunnen ingaan. De inspirerende gesprekken met de collega's van Adviesgroep KOERS mogen uiteraard ook niet worden vergeten. En wat onze lezers betreft: de kwaliteit van een volgende versie van dit produkt is alleen maar gebaat bij uw commentaar en uw suggesties.

Friso den Hertog

Ed van Sluijs

Maastricht, januari 1995 


\section{Samenvatting}

De effectiviteit van de innovatiefunctie staat in veel bedrijven ter discussie. Goede ideeën moeten worden omgezet in klinkende munt. Dit betekent niet alleen dat kennis effectief moet worden ontwikkeld, maar ook effectief overgedragen en gebruikt. De kennisstromen van de onderneming vragen adequaat management, net als de geldstromen en de materiaalstromen. Het management van kennisstromen is met name van belang bij organisaties waarin:

- de kennisintensiteit toeneemt;

- er sprake is van de invoering van business units;

- de vraag zich steeds meer opdringt waarop het bedrijf zich van andere bedrijven kan onderscheiden; en

- de dienstverlening een steeds belangrijker rol gaat spelen.

Deze studie laat zien hoe het management van kennisstromen in de praktijk van een vijftal industriële en dienstverlenende bedrijven vorm krijgt. De studie schetst welke belangrijke rol het personeelsbeleid daarbij kan spelen. Praktisch elke interventie uit het personeelsbeleid is immers op te vatten als een ingreep in de kennisstroom. De instrumenten van het personeelsbeleid die hierbij worden ingezet zijn niet nieuw, maar wel de wijze waarop zij worden ingezet: ter ondersteuning van de bedrijfsontwikkeling. De studie schetst ten slotte de weg waarlangs een nieuwe kennisstructuur kan worden opgebouwd. De introductie van laterale groepen en de ondersteunende rol van de informatietechnologie komen daarbij aan de orde. Het management wordt in dit proces vooral een borgende rol toebedeeld.

\section{Kennis en competitief voordeel}

Bedrijven worden in toenemende mate kennisintensief. Het competitief vermogen wordt steeds sterker bepaald door de effectiviteit waarmee bedrijven produkten, diensten en processen weten te vernieuwen. Het karakter van de waardeketen verandert daarmee drastisch: van een optelsom van arbeid en kapitaal naar een aanwas van toegevoegde, bestaande en nieuwe kennis. Zeker voor moderne geïndustrialiseerde landen geldt dat op termijn het concurrentievoordeel en de werkgelegenheid afhangt van de wijze waarop zij de kennisintensiteit van hun bedrijven en instellingen weten uit te baten (Davis \& Botkin 1994). De weg terug naar pure prijs- en kwaliteitsconcurrentie lijkt definitief te worden afgesneden door de onstuimig groeiende industrie uit het Verre Oosten.

De verhoogde kennisintensiteit stelt het bedrijf voor nieuwe problemen en uitdagingen. Bedrijven staan voor de opdracht een toenemende variëteit van op maat gesneden produkten en diensten van hogere kwaliteit sneller naar de markt te brengen. De bestaande kennis waaruit zij putten dreigt echter steeds sneller te verouderen. De "halfwaardetijd" van bestaande kennis wordt korter en korter. "Obsolescence" van kenniswerkers dreigt bij ongewijzigd beleid een soort ziekte van Pfeiffer met epidemische afmetingen te worden. De voortdurende ontwikkeling van nieuwe kennis is nodig omdat stilstand in feite achteruitgang betekent. Het probleem daarbij is dat nieuwe kennis effectief gemaakt moet worden: goede ideeën moeten in klinkende munt worden omgezet (Van de Ven, 1986). Daar ligt een struikelpunt voor Europese bedrijven. Investering in R\&D geeft geen garantie voor succes (Coriat, 1994). De meeste grote bedrijven, zoals Philips, DSM en Unilever worden zelfs gedwongen hun R\&D-budgetten terug te brengen. $\mathrm{Zij}$ hebben de laatste jaren bovendien de verantwoordelijkheid voor kennisontwikkeling in belangrijke mate gedelegeerd aan business units. De verkorting van de lijn naar de markt heeft wel als gevolg dat de kennislijnen naar de rest van de onderneming langer worden. De uitdaging die daardoor ontstaat is het vinden van nieuwe wegen om het hele kennissysteem beter te laten functioneren. Hierdoor ontstaat de noodzaak (Nonaka, 1991) om een betere greep te krijgen op processen van kennisontwikkeling, kennisoverdracht en kennisgebruik.

Stroomopwaarts in de innovatieketen zullen ontwikkelaars meer rekening moeten houden met de implicaties van hun keuzes voor degenen die daar stroomafwaarts mee moeten werken. Stroomafwaarts zal men beter moeten anticiperen op hetgeen stroomopwaarts wordt uitge- 
broed. De implicatie van deze ontwikkeling is dat bedrijven naar nieuwe strategieën moeten zoeken om de effectiviteit van de kennisstromen te beheersen. De bestaande managementtechnieken zijn vooral ingericht op de beheersing van routinematige produktieprocessen. Bedrijven hebben getracht planningstechnieken en traditionele organisatieprincipes te gebruiken om innovatietrajecten te beheersen. Het is inmiddels (Cobbenhagen, Den Hertog en Pennings, 1994; Cooper, 1994; Van de Ven, 1986) duidelijk dat een dergelijke mechanistische benadering niet voldoende is om sneller, beter en goedkoper te werken. Innovatieprocessen zijn daarvoor te complex, te onzeker en te chaotisch. Een belangrijke sleutel voor dit beheersingsprobleem wordt geleverd door het personeelsbeleid. In de moderne visie op het personeelsbeleid, het Human Resources Management, wordt de factor arbeid niet als kostenpost, maar als een "asset" opgevat. Die benadering laat zich vooral toepassen op kennisintensieve bedrijven. Medewerkers zijn (Van Assen, 1990, Van Diepen, 1995) daar op de eerste plaats dragers, overdragers en gebruikers van kennis. Elke ingreep in het personeelsbestand is daarbij op te vatten als een ingreep in de kennisstroom. Een absolute voorwaarde is wel dat het personeelsbeleid een actieve factor is in het bedrijfsbeleid en niet ophoudt bij het invullen van opengevallen plaatsen en het overplaatsen van degenen die in het innovatietraject zijn afgevallen. Bovendien zal de benadering van personeelsontwikkeling zich veel sterker moeten richten op de bedrijfsontwikkeling. Personeelsbeleid krijgt hiermee een dubbel gezicht: als een effectief middel voor de ontwikkeling van individuele talenten en als een instrument om kennisstromen beter te doen functioneren.

In dit artikel wordt verslag gedaan van de praktijk van vijf kennisintensieve bedrijven. Het zijn bedrijven die het belang van de kennishuishouding hebben onderkend en vanuit het personeelsbeleid nieuwe benaderingen hebben ontwikkeld die daaraan kunnen bijdragen. Het zijn drie bedrijven uit de dienstensector: Moret, Ernst \& Young, het grootste Nederlandse bedrijf van accountants, belasting- en organisatie-adviseurs; Pink Elephant, een Nederlands bedrijf dat zich toelegt op het management van grote computercentra; en de Schadedivisie van Nationale Nederlanden. De twee industriële bedrijven in deze studie zijn de Belgische poot van het Amerikaanse chemiebedrijf Raychem, en de Nederlandse fabrikant van kopieerapparatuur Océ-Van der Grinten. Voordat de praktijk in deze ondernemingen aan de orde komt, wordt ingegaan op de kenmerken van de kennishuishouding. Ten slotte komen in dit artikel de implicaties voor het bedrijfsbeleid aan de orde.

\section{Het management van de kennishuishouding}

De economen die zich met technologische ontwikkeling bezighouden hanteren een opmerkelijk begrip: belichaamde kennis. Zij doelen daarmee op de kennis die op een of andere manier is neergeslagen in materie: in octrooien, software, expertsystemen, archieven en apparatuur. Onbelichaamde kennis is in die definiëring merkwaardigerwijs de kennis die tussen de oren van de medewerkers is opgeslagen. In het economisch onderzoek wordt vooral aandacht besteed aan die factoren waarmee gerekend kan worden: octrooien, patenten, licenties, R\&D-investeringen en uitgaven voor procesontwikkeling. Factoren die minder grijpbaar zijn, onttrekken zich aan hun aandacht. Datzelfde fenomeen treedt vaak op in bedrijven. Zaken die moeilijk te kwantificeren of in geld uit te drukken zijn, dreigen in het beleid verwaarloosd te worden. Bedrijven sturen net als economen op basis van getallen. De onbelichaamde ("tacit") kennis is een dergelijke, moeilijk in getallen uit te drukken zaak die in het bedrijfsbeleid wordt onderbelicht. In moeilijke tijden laten zij zich snel verleiden om het mes in het dure bestand van kenniswerkers te zetten. Het is immers snel duidelijk welke besparing de afvloeiing van kenniswerkers kan opleveren. De kerncompetenties van een bedrijf laten zich snel afbouwen, maar de wederopbouw kost jaren.

In de afgelopen twintig jaar zijn de meeste bedrijven vrij succesvol geworden in het beheersen van de voorraadkosten en van het kapitaalgebruik. De sleutel tot die beheersing is vooral gezocht in het denken in termen van processen en stromen: de materiaalstroom en de geldstroom. Beheersing wordt procesbeheersing. Dat betekent dat men op de eerste plaats in kaart brengt hoe de geld- en materiaalstroom loopt, de knelpunten probeert te onderkennen en beziet welke short cuts daarin zijn aan te brengen. Vervolgens wordt het proces als in- 
put/output-systeem (cf. Nonaka, 1994; Bohn, 1994) weergegeven en worden voor en na de belangrijkste schakels van het proces meetpunten aangelegd op grond waarvan men tijdens het proces kan bijsturen.

Een dergelijke benadering toegepast op de kennisstroom wint veld bij een aantal kennisintensieve bedrijven. Zij ontwikkelen zich van produktiehuishouding naar een kennishuishouding. Onder die kennishuishouding wordt hier verstaan:

Het proces waarin ten behoeve van de bedrijfsvoering:

- informatie wordt ingewonnen en daaruit kennis wordt ontwikkeld;

- kennis wordt geordend en geïntegreerd;

- kennis wordt opgeslagen;

- kennis wordt onderhouden;

- kennis kan worden opgeroepen en overgedragen;

- kennis kan worden toegepast.

Informatie wordt in deze definitie (Bohn, 1994, pp.61-62) opgevat als "georganiseerde of gestructureerde gegevens over een systeem", of: "betekenisvolle gegevens". Kennis gaat verder. Kennis maakt het mogelijk om voorspellingen te doen over dat systeem, om oorzakelijke verbanden aan te geven en uitspraken te doen over wenselijke beslissingen. Kennis krijgt voor de organisatie pas waarde wanneer zij zich beweegt van kennisontwikkelaar naar kennisgebruiker. Binnen organisaties zijn patronen te onderkennen waarin die kennisbewegingen plaatsvinden: de kennisstromen. Bijvoorbeeld bij produktontwikkeling: van de markt naar de ontwikkeling, van produktontwerpers naar procesontwerpers, en van de "field service" naar marketing. Over een heldere kaart van kennisstromen binnen bedrijven beschikken wij niet. De kennisstromen vormen immers geen statisch gegeven. Een vergelijking dringt zich hier op met de sterk wisselende stromen en getijden in zanderige stroomgebieden voor de kust van Engeland en die van de Nederlandse en Duitse Wadden. Voortdurend blijven stromen variëren op het ritme van de tijd en de beperkingen van de ruimte.

Het management van de kennisstromen is erop gericht condities te scheppen waaronder de voor het bedrijf belangrijke kennisstromen worden versterkt. Dat impliceert dat:

- kennis die voor het bedrijf nu en in de toekomst van vitaal belang is wordt geïdentificeerd;

- bestaande en nieuwe routes voor de verspreiding van kennis worden aangegeven;

- passende beleidsinstrumenten worden geselecteerd waarmee de kennishuishouding kan worden gestuurd;

- criteria worden benoemd waaraan de kennishuishouding kan worden getoetst.

\section{Complexiteit van de kennisstromen: tijd en ruimte}

Terwijl de druk op de beheersing van de kennishuishouding in de laatste jaren alleen maar is gegroeid, is ook de complexiteit van die kennishuishouding enorm toegenomen. Twee kenmerken van het innovatieproces spelen daarbij een rol.

Het eerste kenmerk heeft betrekking op de ruimtelijke dimensie van innovatie. Die ruimtelijke dimensie wordt in figuurlijke zin zichtbaar in de organisatorische begrenzingen en afstanden binnen het bedrijf. Bij innovatie wordt een beroep gedaan op een veelheid van groeperingen. Een belangrijk deel van die groepen is gebaseerd op een bepaalde discipline (chemische engineering, fysica, sterkstroom) en andere op basis van functies die in het bedrijf vervuld moeten worden (inkoop, kwaliteitszorg). In bedrijven zijn die functies en disciplines veelal ook letterlijk in verschillende ruimtes ondergebracht. Dat geldt evenzeer voor de organisatorische eenheden die alleen al vanwege de geografische spreiding van het bedrijf op verschillende plaatsen werken. Ten slotte ziet men dat innovatie steeds meer een resultante is van samenwerking tussen toeleveranciers en afnemers. De organisatorische grenzen hebben daarmee niet langer alleen betrekking op de binnengrenzen, maar ook op de buitengrenzen van de onderneming. Kennis is geen statisch gegeven, maar "stroomt" dwars door organisatorische gren- 
zen. Innovatie vraagt daarmee in toenemende mate om het doorbreken van die organisatorische grenzen en om het verkleinen van organisatorische afstanden. Multidisciplinaire teams (Nonaka, 1994) vormen binnen veel bedrijven daarop het logische antwoord. Aan dergelijke teams worden hoge eisen gesteld. Het komt erop aan een gemeenschappelijke taal te ontwikkelen waardoor het mogelijk is binnen de grenzen van het team verschillende disciplines en functies effectief met elkaar te laten communiceren.

Het tweede kenmerk heeft betrekking op de tijdsdimensie van innovatie. De ontwikkeling van een produkt of een proces is een activiteit met een begin en een einde. Het is een tijdelijke activiteit waarvoor tijdelijk een organisatievorm gevonden moet worden. Een geëigende vorm is het projectteam dat werkt binnen duidelijke tijdsgrenzen. Die tijdsgrenzen staan echter onder druk. Projecten volgen elkaar steeds sneller op en lopen vaak in elkaar over. Het gevolg is dat ook de tijdsgrenzen vervagen. Daarnaast wordt de tijdsdimensie manifest in de volgorde van handelingen afgezet op de tijdsas. Voorheen werd innovatie opgevat als een zuiver sequentieel proces. Men zou een vergelijking kunnen maken (Nonaka en Takeuchi, 1986) met een estafette: een race in één vastgestelde richting zonder zijsprongen of stappen terug. Innovatie laat zich in de praktijk niet in een dergelijk keurslijf wringen. Processen zijn eerder iteratief dan sequentieel van aard. Procesfasen dienen te overlappen. Stappen terug zijn van tijd tot tijd noodzakelijk. Keuzes die stroomopwaarts in het innovatietraject worden gemaakt hebben belangrijke consequenties voor degenen die stroomafwaarts werken en omgekeerd. Een voortdurende vooruit- en terugkoppeling is nodig om op tijd processen te implementeren die ook "werken" en produkten en diensten te introduceren die direct aansluiten bij behoeften in de markt. Zo is bij concurrent engineering sprake van het gelijktijdig ontwikkelen van produkt en proces binnen één en hetzelfde (meestal tijdelijke) organisatorische verband. Formele procedures en planningstechnieken vormen maar een beperkte oplossing voor dit beheersingsprobleem en soms zelfs een belemmering. Bij teamwerk wordt de groep verantwoordelijk gesteld voor al die zaken die in de reguliere organisatie zo moeilijk te regelen zijn. Men brengt een bont pluimage van deskundigen bijeen, geeft hen een bepaalde zelfstandigheid en verwacht dat daardoor een motiverende omgeving ontstaat waarin creativiteit kan gedijen.

\section{Personeelsbeleid}

Bij het managen van de kennishuishouding ontstaat er een nieuw perspectief voor het personeelsbeleid. Immers, praktisch alle interventies uit het personeelsbeleid, zoals werving, selectie, loopbaanbegeleiding, opleiding en training en beloning zijn te beschouwen als ingrepen in de kennisstroom. Bij werving en selectie haalt men niet alleen nieuwe medewerkers binnen maar tegelijkertijd nieuwe kennis. Bij overplaatsingen wordt kennis en ervaring van de ene sector van het bedrijf naar de andere overgebracht. Loopbaanbegeleiding resulteert niet alleen in individuele groei van medewerkers, maar geeft ook een pad aan waarlangs kennis kan worden geïntegreerd en geaccumuleerd. Bijzonder van belang daarbij is de kennisoverdracht over functies heen. Opleidingen stomen niet alleen medewerkers klaar voor een functie, maar dienen ook om nieuwe kennis binnen de onderneming te verspreiden. Ook beloning is in dit kader een belangrijke factor. Het levert een instrument om kennisvergaring en competentieontwikkeling te stimuleren.

\section{Kennismanagement in de praktijk}

Kennismanagement staat nog in de kinderschoenen. Er zijn echter tal van ondernemingen die op dit terrein belangrijke stappen voorwaarts hebben gezet. Zij hebben bestaande instrumenten uit het personeelsbeleid ingezet om een strategisch doel te bereiken: het versnellen en verbeteren van de kennisstroom dwars door de binnen- en buitengrenzen van de organisatie. De volgende vijf cases zijn daarvoor illustratief. Het zijn geen "glamour-cases". Het betreft wel "het onderhanden werk" van goed draaiende ondernemingen die ernst hebben gemaakt met een actieve inzet van het personeelsbeleid in de bedrijfsontwikkeling. 


\section{Pink Elephant: Mensen vormen ons kapitaal}

Pink Elephant is onderdeel van de RCC-groep. Het bedrijf werd in 1980 opgericht ter ondersteuning van computer operators en systeembeheerders. Het bedrijf werkte in het prille begin met studenten van technische universiteiten die geld wilden verdienen of hun studie (nog) niet afgemaakt hadden. Inmiddels telt Pink Elephant 650 medewerkers en rekent het tal van grote multinationals tot zijn klanten. Het bedrijf is allang geen job shopper meer die op een efficiënte manier de gaten vult die in de interne computer services van de klanten zijn gevallen. Het heeft zich ontwikkeld als een bedrijf dat de professionele norm voor het beheer en exploitatie van reken- en informatiecentra in Nederland heeft neergezet. Het bedrijf levert een brede scala van diensten, variërend van het beheer van computersystemen, consultancy, audits, opleiding en training en interim management tot het volledig overnemen van de zorg van de automatiseringsinfrastructuur. Het bedrijf is in de laatste vijf jaar sterk gegroeid. Het telde in 1988385 en in 1993629 medewerkers. In die periode steeg de omzet van 15.8 mln gulden naar 48.0 mln gulden.

\section{Een veranderende technologie en een veranderende markt}

De groei van het bedrijf past in een ontwikkeling waarin bedrijven ernaar streven activiteiten die niet tot de kernactiviteiten behoren, af te stoten aan gespecialiseerde bedrijven, die deze efficiënter en professioneler kunnen uitvoeren. Zij zijn zich bewust geworden dat $80 \%$ van de automatiseringskosten aan beheer worden besteed. Zij hebben via Pink Elephant gekozen voor een meer procesmatige invulling van het beheer. Bij de start van het bedrijf stond die ontwikkeling echter nog in haar kinderschoenen. De computercentra-bedrijven die op deze markt opereerden leverden vooral capaciteit om de gaten op te vangen die in de personeelsbezetting van de continu draaiende computercentra vielen. Ze boden hun klanten op de eerste plaats flexibiliteit door op onverwachte momenten te kunnen inspringen, en op de tweede plaats efficiency omdat zij in staat waren de diensten tegen lagere kosten dan bij intern beheer te leveren. Die opportunistische benadering zette zoden aan de dijk in een tijd waarin de operatie van een computercentrum vooral een routine-aangelegenheid vormde. Het leek er tot het midden van de jaren tachtig op dat de technische ontwikkeling van computersystemen de operatie alleen maar zou vereenvoudigen. Die ontwikkeling is in de laatste jaren weer duidelijk omgebogen. Het beheer van computercentra is een professionele aangelegenheid geworden, waarbij hoge eisen aan de operators, systeembeheerders en hun management wordt gesteld. De vergelijking met de procesindustrie dringt zich hier op. De systemen waarmee gewerkt wordt, zijn zeer complex en kostbaar. Bij dergelijke systemen kan een kleine fout zeer ernstige gevolgen hebben. De kans dat dergelijke fouten optreden is niet groot, maar op het moment dat zij optreden is een zeer snelle en adequate reactie vereist.

\section{Systeembeheer als kerncompetentie}

Pink Elephant was in Nederland het eerste bedrijf dat deze ontwikkelingen onderkende: een groeiende markt door het streven naar outsourcing en de noodzaak om het vak van systeembeheer te professionaliseren. Men besefte al in een vroeg stadium dat het snel groeiende bedrijf niet lang zou kunnen blijven teren op de factoren prijs en flexibiliteit alleen. Een dergelijk beleid is immers kopieerbaar. Dat geldt met name voor een ongedisciplineerde markt zonder normen en standaarden, waarin de concurrenten als "cowboys" rondrijden. Op de langere termijn zou het bedrijf alleen levensvatbaar kunnen blijven wanneer het zelf de norm zou zetten voor de ontwikkeling in het vak van systeembeheer. Met andere woorden, het bedrijf dat als personeelsvoorziening begonnen was veranderde al snel in een innovatieve onderneming, die in het eigen vakgebied voorop loopt. Men kan hierin het streven naar kerncompetenties herkennen (Prahalad \& Hamel, 1991). Dat zijn de vaardigheden die creatief worden ingezet om produkten en diensten te leveren die andere bedrijven niet kunnen leveren en waarmee men nieuwe markten "schept".

Op de markt waarop Pink Elephant opereerde ontbrak het aan een professionele norm. Er was geen sprake van een leidende en binnen de branche geaccepteerde visie op het vak. Er was evenmin sprake van een op maat gesneden gebouw van opleidingen. Op het moment dat de markt een nieuw perspectief bood en de technologische ontwikkeling daarom vroeg, ontstond er een gat waarin Pink Elephant zonder lang te aarzelen in sprong. Men introduceerde 
in Nederland een methode die op een systematische manier alle beheersprocessen beschrijft: ITIL. ITIL staat voor: The Information Technology Infrastructure Library en is ontwikkeld door CCTA, de instantie die de Britse overheid adviseert op het terrein van informatietechnologie. Deze ontwikkeling staat niet stil. ITIL wordt verder vormgegeven door de implementatie-ervaringen die Pink de afgelopen jaren opdeed bij klanten. Men zou hier van "lead users" (cf. Von Hippel, 1986) kunnen spreken.

\section{Sturen op kennisontwikkeling}

Het succes van Pink Elephant is niet alleen toe te schrijven aan de wijze waarop men gebruik maakte van het moment. Doorslaggevend is de wijze waarop Pink Elephant haar innovatiestrategie heeft verbonden met een integrale visie op het management van de kennisstroom. Daarin spelen de instrumenten van het personeelsbeleid een grote rol. Pink Elephant heeft vanaf het begin onderkend dat het management van de "Human Resources" de basis van haar bedrijfsbeleid vormt. Dit komt onder meer tot uitdrukking in de in 1989 geformuleerde missie: Pink Elephant heeft de ambitie om "kwaliteitsmarktleider in het volledig beheer en exploitatie van IT op locatie te worden". En: "het beste bedrijf om voor te werken". Die missie is in de ontwikkeling van Pink Elephant geen loze kreet gebleken. Het is gelet op de ambitie van het bedrijf een absolute noodzaak. 90\% van het werk wordt ten huize van de klant verricht. Dit betekent dat voortdurend geïnvesteerd moet worden in de band met de onderneming. Bovendien heeft Pink Elephant gekozen voor het opkweken van de eigen staf. Ongeveer $10 \%$ van de brutoloonsom wordt besteed aan de ontwikkeling en het onderhoud van de kennisorganisatie.

Een goede vakopeiding. De filosofie van Pink Elephant is niet om de opgedane kennis alleen voor zichzelf te houden, maar om een standaard in het vakgebied te zetten. Met andere woorden: er werd een markt gecreëerd door de eigen kennis zo effectief mogelijk over te dragen. Om beheer als vak neer te zetten is in samenwerking met de Rijkshogeschool IJsselland een HEAO-opleiding opgezet die specifiek in beheer opleidt (HEAO-BI/Beheer van Automatiseringsmiddelen). Door deze Hogeschool werd samen met Pink Elephant een opleiding voor systeembeheer opgezet. Het toepassingsgerichte gedeelte wordt door medewerkers van Pink Elephant verzorgd. De opleiding wordt ook gebruikt voor de professionalisering van de eigen (jonge) medewerkers. Pink Elephant investeert fors in de opleiding van het personeel: 10\% van de brutoloonsom. Een belangrijk deel van de intern ontwikkelde opleidingen wordt daarbij weer te gelde gemaakt door ze op de markt aan te bieden.

De koppeling van ontwikkeling en opleiding. Op het moment dat het bedrijf een nieuwe dienst op de markt brengt, spreekt het vanzelf dat de medewerkers die dienst kunnen uitvoeren. Een snelle en goede overdracht van ervaring van het ontwikkelingsstadium naar de normale bedrijfsvoering is dan ook van het hoogste belang. Dit heeft het bedrijf ertoe gebracht om de ontwikkelings- en de opleidingsfunctie in één en dezelfde organisatorische eenheid, de werkmaatschappij "Education \& Development", onder te brengen. Dit levert op twee manieren resultaten op. Op de eerste plaats wordt al bij het vormgeven van nieuwe diensten en processen rekening gehouden met de overdracht. Daarnaast kunnen hierdoor de nieuwe routines en instrumenten snel worden overgedragen binnen het bedrijf. De Education \& Development heeft voor dit doel ook simulatoren ontwikkeld. Men kan op PCs zeer natuurgetrouw de praktijkproblemen met grote mainframes nabootsen. Education \& Development kan deze functie vervullen omdat het een centrale rol speelt in het "orkestreren" van de talrijke ontwikkelingswerkgroepen en vakgroepen waarin ongeveer 100 medewerkers participeren.

Het loodsensysteem. Pink Elephant heeft een eigen duidelijke standaard ontwikkeld voor haar dienstverlening. Die standaard moet worden ingevuld voor de medewerkers in het veld. Dat is voor Pink Elephant de reden om duidelijke ontwikkelingspaden voor de loopbaanontwikkeling van individuele medewerkers uit te zetten. Elke medewerker krijgt een eigen "loods" bij de personeelsafdeling. Met de loods worden twee keer per jaar loopbaangesprekken gevoerd. De basis voor die gesprekken is de "vaardighedenkaart" ("skills map"), waarop wordt bijgehouden over welke kennis en vaardigheden de medewerker al beschikt en welke nog ontwikkeld moeten worden. Die ontwikkeling is gedeeltelijk een kwestie van opleidingen. Belangrijker is nog dat op grond van de vaardighedenkaart een ervaringspad wordt uitgezet. Dat gewen- 
ste ervaringspad vormt een uitgangspunt voor de inzet van medewerkers in projecten. Dit betekent dat de allocatie van medewerkers in projecten wordt gehanteerd als een belangrijk stuurmiddel om de persoonlijke groei van medewerkers te stimuleren en daarmee de kerncompetenties van het bedrijf te verankeren in de "Human Resources".

Eind 1993 is een start gemaakt met het opstellen van een loopbaanontwikkelingsplan. In dit plan wordt een koppeling gemaakt tussen de diensten die (zullen) worden aangeboden enerzijds en de capaciteiten van medewerkers, loopbaanmogelijkheden en begeleidingsinstrumenten anderzijds. Dit plan verschaft duidelijkheid aan medewerkers, begeleiders en aan de organisatie als geheel.

\section{Moret, Ernst \& Young: Nieuwe ideeën komen uit de markt}

Bij innovatie zal een buitenstaander niet in de eerste plaats aan de dienstensector denken en daarbinnen nog minder aan de kantoren van acccountants en belastingadviseurs. Dat beeld van conservatisme is inmiddels bij vele accountancy-bedrijven allang achterhaald door de werkelijkheid. De accountancy-branche is de laatste jaren gedwongen op een ingrijpende manier de bakens te verzetten. Op de eerste plaats omdat veel accountancy-bedrijven internationaal werkende klanten hebben en daardoor zelf op internationale schaal moeten opereren. Op de tweede plaats omdat de klant van het accountancy-bedrijf een complete dienstverlening vraagt: interne controle, externe berichtgeving, de inrichting van de administratieve organisatie, automatisering, belasting- en organisatie-adviezen. De rol van het accountancy-bedrijf is daarmee veel breder geworden als voorheen. De toepassing van de informatietechnologie (IT) is een derde factor. Het wordt met behulp van die informatietechnologie steeds beter mogelijk om de benodigde berichtgevingsinformatie direct af te tappen uit de administratieve organisatie van de klant. Ten slotte is er een nieuw perspectief ontstaan op de aanbieding van nieuwe diensten op tal van terreinen. Men denke aan: advisering bij buitenlandse investering en vestiging van bedrijven, de inrichting van milieu-zorgsystemen, advisering bij fusies en overnames, en advisering over onroerend-goedbelasting. Door deze ontwikkeling is het moderne accountancy-bedrijf een multinationale onderneming geworden die voortdurend nieuwe ervaringen in nieuwe diensten omzet, interne processen vernieuwt en kennis intern overdraagt en ter beschikking van zijn klanten stelt. Het is geen wonder dat communicatie, kennisbeheer, opleiding en vorming de basiselementen vormen van de bedrijfsstrategie van veel grote bedrijven in deze branche.

Moret, Ernst \& Young (MEY) is de grootste Nederlandse dienstverlener op het terrein van accountancy, belasting- en organisatie-adviezen in Nederland. MEY is als maatschap in federatief verband aangesloten bij Ernst \& Young International concern. MEY is ontstaan uit een bundeling van een aantal Nederlandse accountancy-firma's en bood in 1993 werk aan rond 4200 medewerkers. De omzet in dat jaar bedroeg rond $f 750 \mathrm{mln}$. MEY besteedt ongeveer 7$8 \%$ van de omzet aan opleidingen. In die opleidingen zijn twee stromen te onderscheiden. De eerste en meest dominante stroom is gericht op de reguliere professionele ontwikkeling van het personeel. In het personeelsbeleid van MEY ligt de nadruk op personeelsontwikkeling. Bij de werving van personeel staat dat dynamische perspectief al voorop. Nieuwe personeelsleden weten dat zij in een bedrijf terechtkomen waarin voortdurend moet worden bijgeleerd. Dat proces loopt door tot aan het einde van de loopbaan en heeft betrekking op elk niveau. Zo zijn ook de vennoten en de gecertificeerde accountants verplicht elk jaar ten minste 40 uur aan bijscholingsactiviteiten te besteden.

De tweede hoofdstroom heeft betrekking op de vernieuwingen in de belangrijkste diensten en processen in het bedrijf. De omvang van het bedrijf en zijn verbindingen met E\&Y International bieden een perspectief op het gebruik van een schat aan gemeenschappelijke kennis. MEY voert dan ook een duidelijk innovatiebeleid. Dit innovatiebeleid draagt bij MEY de volgende kenmerken.

Nieuwe ideeën komen vrijwel altijd uit de markt voort

MEY is als de meeste collegabedrijven in de branche sterk regionaal georganiseerd en onderhoudt langdurige contacten met klanten. In dit verkeer met de klant komen regelmatig ideeën 
voor nieuwe diensten naar boven. Zij dragen in eerste instantie bijna altijd het karakter van een probleem waar een klant mee zit. De eerste fase van de ontwikkeling is dat een dergelijk probleem wordt vertaald in de ruwe schets van een produkt. Men denke bijvoorbeeld aan de problematiek van de onroerend-goedbelasting. In discussies van de belastingadviseurs van MEY met klanten komt het idee naar voren om een nieuw produkt te ontwikkelen waarmee bedrijven betere beleidskeuzes kunnen maken en hun uitgaven beter kunnen beheersen. Door de regionale adviseurs wordt een ruwe schets van het produkt gemaakt. Het produkt is een soort handleiding. De feitelijke ontwikkeling van het produkt vindt na afstemming met de centrale MEY-organisatie en met de collega's uit andere regio's weer lokaal plaats. Het produkt wordt pas op de markt gebracht wanneer het zijn nut in de praktijk bewezen heeft.

Nieuwe ideeën moeten in het eigen bedrijf aanslaan

Het zijn de regionale kantoren en de mensen die daar werken, die de nieuwe diensten uiteindelijk aan de man of vrouw moeten brengen. Een accountancy-maatschap werkt in die zin net als een medische maatschap. De doktoren zelf bepalen uiteindelijk welke medicijnen zij voorschrijven. Voordat bij MEY werkelijk geïnvesteerd wordt in de ontwikkeling van het produkten moet het produkt intern "verkocht" worden. Elk nieuw produkt vraagt zowel in het voortraject waarin de specificaties worden vastgesteld als in het natraject waarin de nieuwe vakkennis moet worden overgedragen een intensieve communicatieslag. MEY kent een systematiek van vakbijeenkomsten waarin op verschillende niveaus van de organisatie voortdurend wordt gecommuniceerd over de nieuwe behoeften aan diensten uit de markt, voorstellen voor produktontwikkeling en de implementatie van nieuwe produkten of diensten. Innoveren betekent in die zin voor MEY: voortdurend communiceren.

Innovatie in een gedecentraliseerd bedrijf vraagt om "orkestratie"

MEY is een sterk gedecentraliseerd bedrijf. De ontwikkeling van de nieuwe dienst vindt in nauwe samenwerking met klanten plaats. Ook hier zou men van "lead users" (Von Hippel, 1986) kunnen spreken: klanten die zodanig geïnteresseerd zijn in de nieuwe produkten dat zij ook bereid zijn als proefveld een extra inspanning te leveren. De kennis moet vervolgens echter weer beschikbaar worden gemaakt voor de rest van het bedrijf. Deze wisselwerking tussen lokale praktijk en het algemeen gebruik binnen de maatschappen vraagt om een centrale schakelfunctie. Die is bij MEY in een kleine centrale unit "vakontwikkeling" ondergebracht. Eén van de taken van die unit is om budgetten ter beschikking te stellen waarmee de lokale ontwikkeling kan worden ondersteund. De unit werkt in de praktijk als een soort "vliegwiel", waarmee lokale initiatieven kunnen worden versterkt. Daarnaast is een vorm van kwaliteitsbewaking nodig. Het meest belangrijk is echter de orkestratie van de communicatie tussen produktontwerpers en de andere produktgebruikers binnen MEY. MEY heeft ervoor gekozen om in deze orkestrerende centrale functie de vakontwikkeling en de overdracht en training te integreren.

Innovatie betekent opleiden, opleiden en nog eens opleiden

Het is van groot belang dat de nieuwe produkten zo snel mogelijk operationeel worden gemaakt in de regionale organisatie. Dat is alleen mogelijk door een directe koppeling van ontwikkeling en opleiding. Men zou kunnen zeggen dat de opleiding van eigen medewerkers en van de klant een geïntegreerd deel van de produktontwikkeling vormt. Als een produkt niet effectief kan worden overgedragen is het geen volwaardig en volwassen produkt.

De aanpak van MEY laat zien dat innovatie van produkten en diensten, het opdoen van lokale praktische ervaring, overdracht van kennis, en personeelsbeleid deel uitmaken van één en hetzelfde basisproces in de organisatie.

\section{Raychem: Managing personal growth}

De chemie is kapitaalintensief. Als men dwaalt over de uitgebreide bedrijfsterreinen tussen de doolhof van pijpen en leidingen, komt men slechts af en toe mensen tegen. Voor de economie en werkgelegenheid is de chemie echter van strategische betekenis, omdat het een hoogwaardige schakel biedt in het netwerk van leveranciers en afnemers. De betekenis van de chemie voor economie en werkgelegenheid komt ook voort uit het feit dat het een kennisintensieve be- 
drijfstak is. Die kennisintensiteit betreft elke schakel van het bedrijfsgebeuren: van de research en de produktontwikkeling in het lab, de engineering en vormgeving van produktieprocessen, tot het onderhoud, de produktie en de marketing en verkoop. In elke schakel van bedrijvigheid moet het vakmanschap, de kennis en ervaring voortdurend worden aangepast aan de stand van de technologie en de wensen van de afnemers. Dat geldt zeker voor marktleiders, die door hun kennisvoorsprong afstand willen nemen tot hun achtervolgers. Raychem is zo'n kennisintensieve voorloper. Raychem is onder meer marktleider op het terrein van warmtekrimpende beschermingsmaterialen. Die worden in allerlei variëteiten gebruikt in de telecommunicatie, pijpleidingssystemen en in de bouw. De kern van de Raychem-technologie omvat vernette en geleidende polymeren, materialen met vormgeheugen, keramieken, kleefstoffen, dunne films, vloeibare kristallen, optische glasvezels en elektrochemie. Men kan hieruit afleiden dat het bedrijf drijft op een intelligente combinatie van chemische en fysische disciplines, met de materiaalwetenschappen in het centrum. De bedrijfsfilosofie is erop gericht het bedrijf voortdurend in beweging te houden. Of zoals de vorige CEO van Raychem Paul Cook (Taylor, 1990, p.104) het uitdrukt: "For an organization to remain innovative it has to be willing - even eager - to obsolete itself as fast as it can".

Raychem heeft in België (Kessel-loo) een belangrijke vestiging met een eigen verantwoordelijkheid voor R\&D, fabricage en marketing. De vestiging telt 1050 personeelsleden, waaronder 250 universitair opgeleiden. Zoals de meeste andere chemische bedrijven is Raychem in de markt een moeilijke periode gepasseerd. Bij Raychem had dit vooral te maken met de dip in de defensie-industrie en in de bouw- en constructiesector. Het bedrijf is echter uit deze recente economische neergang weer naar voren gekomen als het richtinggevende bedrijf in zijn branche. In 1993 was de omzet van de Belgische tak van het bedrijf Bfrs. 10,3 miljard; de winst voor belasting bedroeg Bfrs. 1,2 miljard.

\section{Kerncompetenties}

Raychem's kerncompetentie ligt vooral in het combineren van nieuwe technologische en wetenschappelijke kennis uit verschillende disciplines. Voor het management van Raychem's kennisstromen heeft dat twee belangrijke gevolgen. Op de eerste plaats moet kennis voortdurend vernieuwd worden en moet ervoor gezorgd worden dat de kennis van de medewerkers op peil blijft. Op de tweede plaats moet ervoor gezorgd worden dat de kruispuntproblemen in de kennisstromen beheersbaar blijven. De discipline- of functiegerichte aanvoer van kennis vormt de vertikale as van de organisatie. Langs die as worden de state-of-the-art technologische en wetenschappelijke kennis aangevoerd en verspreid. In de traditioneel werkende organisatie heeft die vertikale stroom de voorrang. In Raychem wordt echter aan de kennisstroom langs de horizontale as voorrang verleend. In die stroom worden in concrete produkten en processen ontwikkeld en worden technologieën aan elkaar geknoopt. Die as loopt direct naar de markt en de druk is daar het hoogste. Disciplines en functies werken in deze stroom hecht samen in multidisciplinaire teams. De voorrang aan de horizontale produktstroom boven de vertikale functionele stroom brengt ook een risico met zich mee. Dat risico houdt in dat men door de dominantie van het project en het produkt het contact met vernieuwingen in specifieke vakgebieden verliest. Juist in het management van dit kenniskruispunt ligt de sterkte van Raychem. Voor de organisatie en het personeelsbeleid betekent dit wel dat men voortdurend de link tussen functies (disciplines) en projecten (produkten) moet bewaken. Het personeelsbeleid biedt hier belangrijke instrumenten.

\section{HRM moet een leerklimaat scheppen}

Het personeelsmanagement heeft zeker een operationele taak binnen Raychem. Daarin verschilt Raychem niet van andere ondernemingen. Het personeelsmanagement vervult echter nog een andere, voorwaardenscheppende rol. Raychem wil een leerklimaat scheppen waarin mensen zich blijven ontwikkelen. Het betekent echter ook een werkomgeving waarin kennis en ervaringen met anderen gedeeld worden. Dat kan alleen door een effectieve overdracht van kennis en ervaring binnen, en vooral ook tussen teams en afdelingen.

\section{Werving van bewegende medewerkers}

De visie van Raychem is duidelijk terug te vinden in het wervingsbeleid. Men zoekt niet alleen naar technici en wetenschappers die goed zijn in hun vak. In de wervingsgesprekken wordt de 
kandidaten al duidelijk gemaakt dat hun toekomstige meerwaarde voor het bedrijf ligt in het vertalen van hun kennis in toepassingen in andere vakgebieden. Dit betekent dat men niet lang in één functie zal werken en dat er binnen het bedrijf geen vaste disciplinegerichte thuisbasis is.

Managing personal growth

Ook bij Raychem wordt in het personeelsbeleid een dynamisch perspectief gevolgd. Op individueel niveau komt dat duidelijk tot uiting in de loopbaanbegeleiding. Daarbij worden twee uitgangspunten gekozen. Op de eerste plaats de kennisbehoefte die uit de business-ontwikkeling voortkomt. Die dient als input voor werving en personeelsontwikkeling. Het gaat dan niet alleen om de invulling van de huidige kerncompetenties van het bedrijf, maar ook om de kerncompetenties van de toekomst. De huidige en gewenste ontwikkeling van kennis en vaardigheden van het individu vormt het andere uitgangspunt. Enkele malen per jaar worden daarover met de medewerkers gesprekken gevoerd. Uit de confrontatie van kennisbehoeften van het bedrijf en van de medewerker resulteert een kloofanalyse.

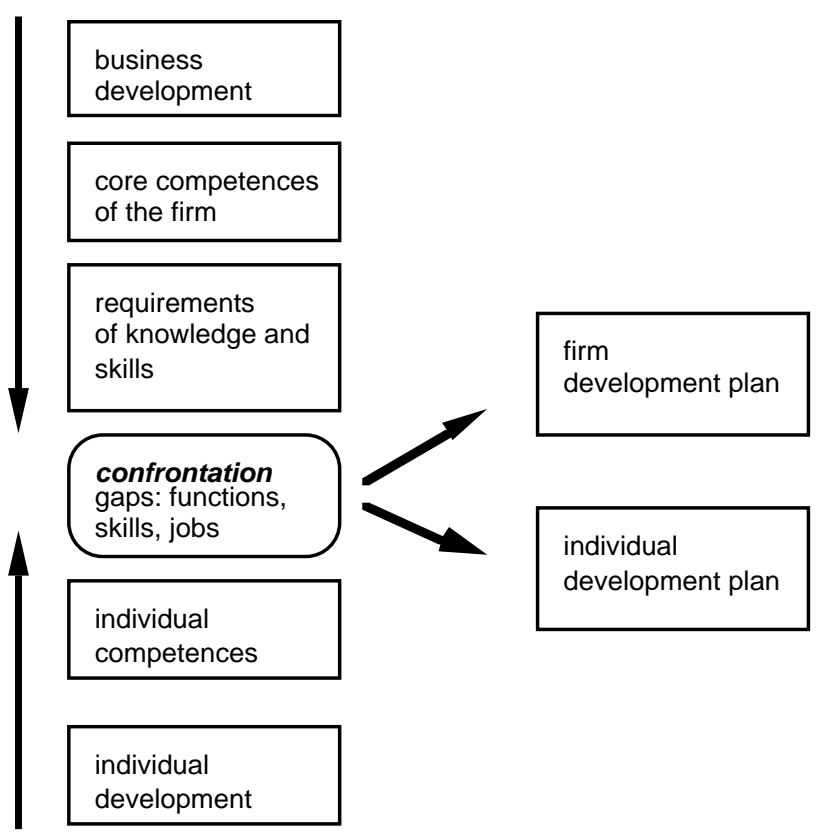

Figuur 1: De ontwikkeling van competence

De kloofanalyse maakt het mogelijk om huidige en toekomstige tekorten in competenties aan te geven. Deze analyse vindt plaats op verschillende niveaus: de kerncompetenties van het bedrijf als geheel, de competenties die binnen en vooral die tussen afdelingen worden ontwikkeld en de kennis en vaardigheden van het individu. Het beeld dat zo ontstaat is vervolgens weer een basis om plannen te maken op het niveau van het bedrijf, de afdeling, het team en het individu. Plannen voor werving, opleidingen, loopbaanontwikkeling en beloning. Bij Raychem streeft men ernaar die plannen "hard" te maken in termen van verantwoordelijkheden, doelstellingen en verwachte prestaties. Met de medewerkers worden gesprekken gehouden om doeleinden bij te schaven, normen te stellen, de voortgang te volgen en om concrete afspraken te maken. Die concrete afspraken hebben voor een belangrijk deel betrekking op de manieren waarop de kennis en ervaring van medewerkers kan worden verbreed en verdiept. Een veelheid van wegen dienen zich hier aan:

- een gerichte opleiding

- werken onder begeleiding van een mentor gedurende een bepaalde periode

- het uitstippelen van een ervaringspad (projecten waarin men achtereenvolgens ervaring kan opdoen 
- detacheringen van ontwikkelaars in het corporate R\&D-lab

- stages bij andere afdelingen

- individuele studies begeleid door een interne coach

- bezoeken aan andere bedrijven, beurzen, field trials, benchmarking-activiteiten

- break-out meetings van functioneel specialisten in de hele organisatie en wereldwijd

- cross-divisionele en cross-site projectgroepen

- het bestuderen van cross-divisionele en cross-site state-of-the-art benaderingen

Belangrijk is dat de kennisontwikkeling ook in de beloning van medewerkers wordt bekrachtigd. Men heeft daarvoor elementen van "skill-based pay" in het beloningssysteem opgenomen.

Kennisstromen dwars door grenzen heen

Niet de functies of de disciplines, maar de stroom van kennis van ontwikkeling naar toepassing staat bij Raychem centraal. In de ontwikkelingsorganisatie heeft het bedrijf in de laatste jaren een ware kanteling doorgemaakt. Het bedrijf heeft zich in haar R\&D-organisatie losgemaakt van de dominantie van de functionele kennisdomeinen. Voorrang heeft de kennisstroom in de richting van de klant. Men werkt in de ontwikkeling van nieuwe produkten met multidisciplinaire teams. Marketing, produktie en engineering zijn al bij het begin van een project bij de organisatie betrokken. Zowel om hun know-how in te brengen als om te kunnen anticiperen op nieuwe ontwikkelingen. Men spreekt met andere woorden "eerder" de kennis aan uit een "later" stadium van het ontwikkelingsproces. Deze omslag laat zich niet invoeren als een formele wijziging van de structuur. Het zijn vooral de gedrags- en communicatiepatronen die moeten worden verlegd. Die cultuurverandering vraagt om het duidelijk formuleren van waarden en normen en om het bekrachtigen daarvan. Dat lukt in de ene afdeling beter dan in de andere. Voortdurend moet worden gewaakt voor een terugval in de oude patronen.

\section{Océ-Van der Grinten: Kennismanagers en personeelchefs}

Océ-van der Grinten levert en produceert produkten en diensten voor de reproductie en representatie van informatie op papier. De produkten behelzen kopieer-, plotter- en printsystemen, inclusief de daarvoor benodigde materialen en onderdelen, zowel voor de kantoormarkt als de tekenkamermarkt. Sinds de oprichting in 1877 heeft onderzoek en ontwikkeling altijd een belangrijke rol gespeeld. Sinds de jaren ' 50 is er meer aandacht besteed aan de produktie en verkoop en is de onderneming behoorlijk gegroeid, onder andere als gevolg van een aantal overnames en de vestiging van dochterondernemingen. Océ-van der Grinten is de Nederlandse moedermaatschappij van de Océ Groep, die actief is in ongeveer 80 landen. De meeste van de produkten worden door Océ zelf ontwikkeld. Direct contact met klanten wordt als cruciaal beschouwd. Sales en Service wordt daarom door eigen ondernemingen verricht. Op deze wijze blijft Océ verzekerd van de benodigde marktinformatie. De doelstelling van de onderneming is het leveren van produkten en diensten die opvallen door hoge kwaliteit, betrouwbaarheid, productiviteit, duurbaarheid, gebruikersvriendelijkheid en milieuvriendelijkheid. Met betrekking tot de kantoormarkt oriënteert Océ zich vooral op de markt van grootverbruikers (meer dan 10.000 kopieën per maand) en in Europa heeft Océ een marktaandeel van meer dan 10\%. In de tekenkamermarkt heeft Océ een marktaandeel van 30\% in Europa en 20\% wereldwijd en is daarmee marktleider. De omzet bedraagt ongeveer 2,6 miljard per jaar. Ongeveer 7\% daarvan wordt geïnvesteerd in onderzoek en ontwikkeling. Océ heeft wereldwijd circa 11.000 mensen in dienst, waarvan zo'n 4.000 in Nederland werken. Zo'n 10\% (1.100 medewerkers) van de totale bezetting is actief in onderzoek en ontwikkeling, vrijwel allemaal in Venlo.

Océ is een relatief kleine onderneming, vergeleken met belangrijke collega's als Xerox, Kodak en Canon. Als gevolg van onder andere de trends naar digitalisering en kleurtoepassingen zijn de kantoor- en tekenkamermarkt sterk en constant aan verandering onderhevig. Om als relatief kleine onderneming haar positie te kunnen handhaven, maakt Océ een aantal strategische keuzes, onder andere met betrekking tot het uitbesteden van de produktie van circa $95 \%$ van de onderdelen. Een aantal strategisch cruciale onderdelen, zoals toners, worden door Océ zelf geproduceerd. Bovendien richt Océ zich vooral op de medium- en hoog-volume-markten. Systemen voor de laag-volume-markt worden op basis van Océ-specificaties geproduceerd door 
toeleveranciers. De relatief kleine omvang van Océ heeft ook consequenties voor het onderzoek en de ontwikkeling. Océ is daardoor niet in staat om ten aanzien van alle nieuwe ontwikkelingen een actieve rol te spelen, maar moet een aantal strategische keuzes maken ten aanzien van onderzoek- en ontwikkelprojecten. Projectselectie is daardoor van cruciaal belang binnen R\&D. Ook wordt het voor Océ steeds belangrijker dat alle ontwikkelprojecten tot succes leiden. Dit vereist nauwe samenwerking tussen R\&D en de diverse business units die verantwoordelijk zijn voor marketing en sales.

$R \mathcal{E D}$ : een veranderende organisatie in een veranderende markt

Tot 1992 waren de R\&D-activiteiten gestructureerd in een matrix-organisatie. De ene zijde van de matrix bestond uit projecten en de andere uit functionele afdelingen, gegroepeerd naar de fase van het R\&D-proces (onderzoek, ontwikkeling en engineering). Medewerkers van de ontwikkel- en engineering-afdelingen werkten eerst $65 \%$ en daarna $75 \%$ van hun tijd in projecten, onder begeleiding van een projectleider. De resterende tijd besteedden zij aan de acquisitie en ontwikkeling van nieuwe kennis door het werken aan gedefinieerde onderwerpen, onder begeleiding van het afdelingshoofd. Binnen de onderzoekafdeling werkte men voornamelijk individueel aan dergelijke gedefinieerde onderwerpen.

Met het toenemende belang van de efficiëntie, effectiviteit en doorlooptijd van de ontwikkeling en innovatie, werd in 1992 besloten R\&D te reorganiseren en meer direct in relatie te brengen met de business units verantwoordelijk voor de marketing, sales, en service. Er zijn nu drie 'business unit R\&D-teams' (BU-teams) binnen R\&D. Deze BU-teams worden geleid door een 'business development manager' (BDM) die tegelijkertijd adjunct-directeur binnen de business units zijn. Elk BU-team heeft een vergelijkbare matrix-organisatie, met op de ene lijn de projecten en op de andere lijn de afdelingen. Elk BU-team bestaat uit de afdelingen Development, Mechanical Engineering, Electronical Systems and Engineering Processes. Deze afdelingen functioneren als capaciteitsgroepen: alle medewerkers behoren tot een afdeling en zijn gealloceerd bij één van de projecten. Doordat elk BU-team min of meer uit dezelfde afdelingen bestaat wordt de overdracht van kennis tussen de afdelingen en het voorkomen van doublures in de activiteiten steeds belangrijker. Meer hierover later. Naast de drie BU-teams, zijn er ook nog twee andere teams: het Groep Research \& Technology-team, dat is gericht op het fundamentele onderzoek en functioneert als een buffer tussen de toepassingsgeoriënteerde BU-teams en de algemeen beschikbare kennis, en het R\&D Resources-team (RDR), die alle ondersteunende R\&D-activiteiten verricht.

De interne acquisitie, uitwisseling en overdracht van kennis

Zoals eerder aangegeven is door de overlap tussen de functionele afdelingen binnen R\&D van groot belang dat de acquisitie, uitwisseling en overdracht van kennis goed gecoördineerd worden om te voorkomen dat er dubbelingen of kennishiaten ontstaan. Hiertoe hanteert Océ een complex systeem van hulpstructuren. Zo zijn er de zogenaamde "Dwarsverbanden". Dit zijn disciplinair georiënteerde groepen bestaande uit afdelingshoofden uit alle BU-teams, die de ontwikkelingen binnen de discipline (bijvoorbeeld mechanical engineering), de externe werving en de interne arbeidsmarkt bespreken. Ook is er een groot aantal werkgroepen die zich bezighouden met specifieke technologieën (bijvoorbeeld toner-overleg), en waarin alle medewerkers participeren die aan deze technologie werken.

Afdelingshoofden als 'mensen en kennismanagers'

Afdelingen binnen een BU-team zijn in feite lege afdelingen. Alle medewerkers zijn constant in projecten werkzaam en zijn ook fysiek bij de projectleider en andere projectmedewerkers gelocaliseerd. De belangrijkste taak van de afdelingshoofden concentreert zich rondom het management van kennis en dus het management van mensen. Met betrekking tot het management van kennis dient het afdelingshoofd ervoor te zorgen dat er een balans bestaat tussen de korte- en lange-termijngerichte onderzoek en ontwikkeling. Ook is hij verantwoordelijk voor de voldoende aanvoer van nieuwe projectideeën en voor het functioneren van de afdeling als platform voor de uitwisseling van technische kennis. Uiteraard vallen deze activiteiten met betrekking tot het management van kennis sterk samen met het management van mensen. Formeel heeft een afdelingshoofd de volgende taken ten aanzien van het management van mensen: de allocatie van medewerkers aan projecten; de lange-termijnontwikkeling van me- 
dewerkers en de lange-termijnontwikkeling van kennis. De allocatie van medewerkers aan projecten draagt bij aan de ontwikkeling van medewerkers, ook al variëren de afdelingshoofden in de mate waarin zij aandacht geven aan dit lange-termijnaspect van de projectallocatie. Met de toenemende nadruk op korte-termijnresultaatgerichtheid worden de projectleiders steeds veeleisender met betrekking tot de kwaliteit van projectmedewerkers. Als gevolg daarvan bestaat het gevaar dat sommige medewerkers niet meer in projecten worden opgenomen. Afdelingshoofden, samen met de coaches binnen de projecten, geven steeds meer aandacht aan de begeleiding en coaching van individuele medewerkers.

\section{Het gebruik van 'klassieke' personeelsmanagementinstrumenten door afdelingshoofden}

De afdelingshoofden functioneren in feite ook als personeelsfunctionarissen en maken daarbij gebruik van de overbekende personeelsmanagementinstrumenten. Met betrekking tot de werving en selectie is het daarbij voor Océ van belang dat niet alleen geselecteerd wordt op basis van technische kennis. Minstens zo belangrijk zijn zaken als professionele attitude, gerichtheid op toepassingen, 'team-player', onafhankelijkheid, flexibiliteit en kwaliteitsbewustheid. Ook voeren de afdelingshoofden eens per jaar beoordelingsgesprekken en zogenaamde 'manager-medewerkers'-gesprekken. Dit laatste type gesprek is georiënteerd op de toekomst en is een tweerichtingsgesprek tussen manager en medewerker. Beide gesprekken vormen de input voor de personeelsplanning. Hiertoe is recentelijk de zogenaamde 'Human Resources Review' geïntroduceerd. Afdelingshoofden dienen jaarlijks een afdelings-resources plan, een loopbaanontwikkelingsreview en een "management development review" te maken. Zodoende is de expliciete aandacht voor de voortgang in individuele en afdelingsontwikkeling verzekerd. Bij dit alles is het opvallend dat de personeelsafdeling een ondersteunende rol heeft en zich hoofdzakelijk richt op informatieverzameling en -levering.

\section{Spanning tussen korte-termijnresultaten en lange-termijnontwikkeling}

Océ hanteerde lange tijd een strategie ten aanzien van de competentie-ontwikkeling die we de 'sandwich'-strategie zouden willen noemen. Projectmedewerkers werkten eerst $65 \%$ en daarna $75 \%$ van hun tijd aan direct projectgerelateerd werk. Dit verzekerde min of meer de acquisitie dan wel ontwikkeling van de op de lange termijn gerichte kennis en vaardigheden. Met de noodzakelijkheid meer aandacht te besteden aan resultaatgerichtheid is dit percentage gestegen naar $90 \%$. Hierdoor is voor medewerkers nog maar $10 \%$ van hun tijd beschikbaar voor het bijhouden en/of uitbreiden van hun competenties. En zelfs deze 10\% staat onder grote druk; in veel gevallen is het vrijwel onmogelijk naast het projectwerk nog iets anders te doen. Ook is er tussen verschillende opeenvolgende projecten nauwelijks tijd om bij te komen van de spanningen en stress van het project of om de energie- en competentietank bij te vullen. Als gevolg daarvan bestaat het gevaar dat er geen voldoende tijd en mogelijkheden meer zullen zijn om minder goed functionerende medewerkers te begeleiden, laat staan om aandacht te geven aan de lange-termijnontwikkeling van medewerkers en kennis. Océ is zich terdege bewust van deze risico's en is bezig een systeem te ontwikkelen waarmee de projectallocatie gericht kan worden op zowel de korte-termijnprojectresultaten als de lange-termijncompetentieontwikkeling en innovatie.

\section{Nationale Nederlanden: kennisborging}

"Verstand van verzekeren" is meer dan een kreet uit de televisiereclame. Kennis van en ervaring met verzekeringsprodukten, verzekeringsrisico's en verzekeringsmarkten vormen voor de grote verzekeringsbedrijven een kostbaar goed. Een goed dat in veel ondernemingen gekoesterd werd in de formele structuur van "functionele" of "produktgerichte" afdelingen. Een aantal grote verzekeraars heeft desondanks recentelijk afstand genomen van die functionele structuur en heeft gekozen voor een marktgerichte organisatie. De verandering in de verzekeringsmarkt heeft sterk tot die ontwikkeling bijgedragen. De markt is aan het veranderen van een stabiele zelfvoldane markt in een vechtmarkt waarin de kwaliteit van de dienstverlening en de kosten doorslaggevend zijn geworden. Een vertrouwenwekkende naam en een gezond beleggingsbeleid is niet meer voldoende om te dingen naar de gunsten van tussenpersonen en verzekerden. Net als in tal van andere gebieden is de aanbodmarkt in een vraagmarkt veranderd. Bovendien vinden in de omringende maatschappij tal van ontwikkelingen plaats die de positie van de verzekeraar doen veranderen. Men denke aan de maatschappelijke noodzaak 
van het drukken van de kosten van de gezondheidszorg. Er wordt hier een nieuw spel tussen verzekeraars als inkopers van gezondheidszorg en de aanbieders van gezondheidszorg gespeeld met als doel de lasten te drukken bij een gelijkblijvende kwaliteit. Andere ontwikkelingen waarop de verzekeraar moet inspringen zijn: de voortdurende veranderingen in het stelsel van sociale voorzieningen en de stijgende schadelast door een verminderende sociale controle in onze maatschappij. In de sector van de schadeverzekeringen zetten deze ontwikkelingen de marges sterk onder druk en wordt hard gevochten om marktaandeel.

De schadedivisie van Nationale Nederlanden heeft in deze ontwikkeling een belangrijke stap gezet om slagvaardiger te kunnen samenwerken met de tussenpersonen. De functionele organisatie van produktgroepen (brand-, auto-, inkomens-, reisverzekeringen, enz. ) is vervangen door een stelsel van resultaatverantwoordelijke regionale units, waarin het hele pakket van diensten wordt aangeboden. Binnen deze units werken verzekeringsteams die zodanig zijn opgesteld dat de tussenpersonen elke keer bij een vast team terecht kunnen (Den Hertog 1994). De produktspecialisten uit de oude organisatie zijn in de nieuwe organisatie ondergebracht in marktgerichte groepen. Het gevaar dat door deze kanteling van de organisatie met name produktgerichte verzekeringskennis en ervaring zou kunnen weglekken werd in het herontwerpproces al in een vroeg stadium onderkend. Aan wie zou in de nieuwe organisatie de verantwoordelijkheid voor de ontwikkeling, opslag en borging van de essentiële vakkennis kunnen worden toebedeeld? Hoe zou deze kennis effectief ter beschikking van de regionale teamleden kunnen worden gesteld? Er werd een aparte ontwerpgroep met vertegenwoordigers van de betrokken functies de opdracht gegeven om een structuur voor "kennisborging" te ontwerpen. Na talloze gesprekken met betrokkenen werd gekozen voor de ontwerpoptie die in figuur 2 is weergegeven.

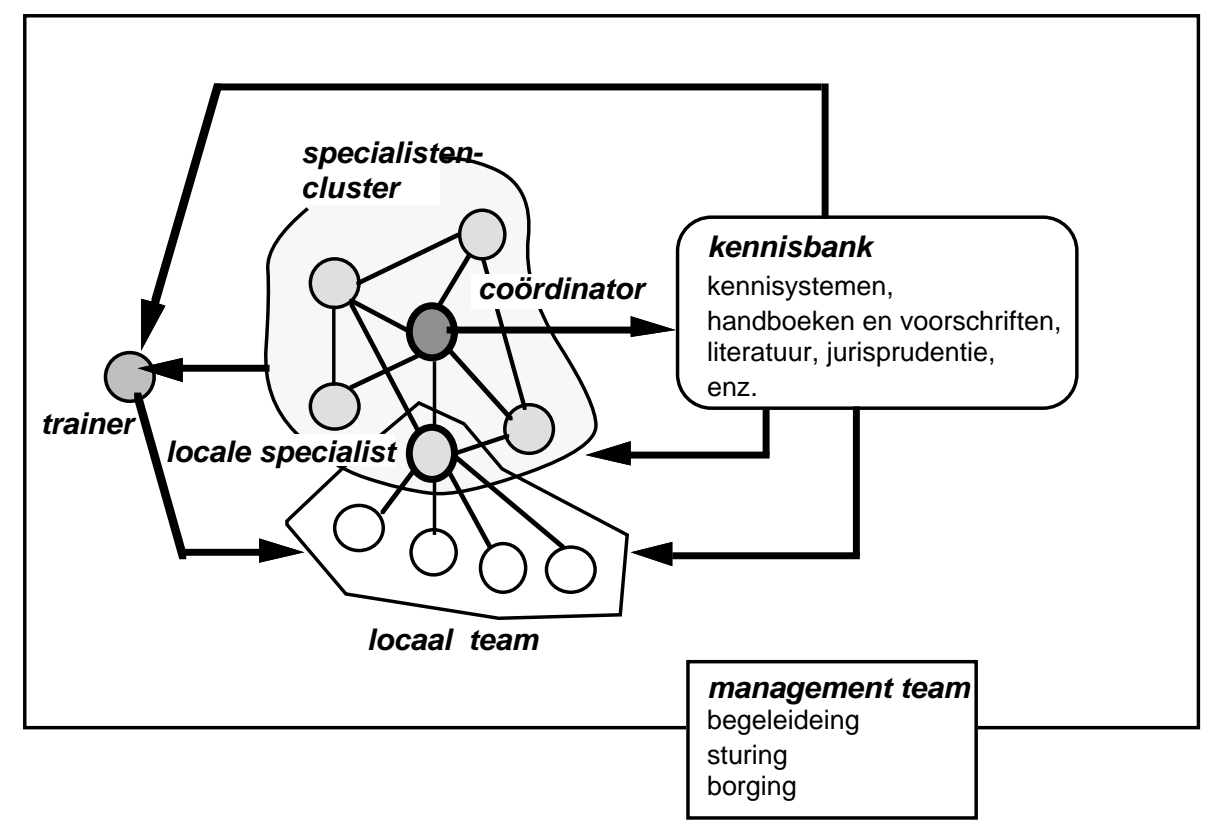

Figuur 2: Management van kenniscycli

In dit ontwerp kunnen drie functies worden onderscheiden:

De specialist. Elke regionale unit beschikt over een aantal specialisten met een eigen veld van competentie. Dat kan een bepaald produkt zijn, een groep produkten, de acceptatie van risico's of de schade-afhandeling. Deze specialisten fungeren als een vraagbaak in hun unit. Ze bundelen vragen, problemen en nieuwe ideeën en bespreken deze met hun collega's uit de andere regio's.

De coördinator. Hij of zij is lid van de divisiestaf en zit de bijeenkomsten van de specialisten clusters voor. De coördinator is verantwoordelijk voor de aanpassingen van de richtlijnen en voorschriften voor het accepteren van een risico (de "polis") en de beoordeling van schade 
claims. Deze aanpassingen van richtlijnen en voorschriften worden opgeslagen in een kennisbank. Dat is een systematische verzameling van kennisdragers: kennissystemen, handboeken, voorschriften en lesmateriaal. Nieuwe kennis wordt vervolgens overgebracht naar de regionale teamleden. De coördinator is verder verantwoordelijk voor het op peil houden van de verzekeringskennis op zijn of haar gebied en voor de ontwikkeling van nieuwe kennis. Dit betekent dat van hem of haar een belangrijke bijdrage wordt verwacht bij de ontwikkeling van nieuwe produkten. De coördinator heeft ook de taak om opleidingsbehoeften in de regionale units te inventariseren en om samen met de opleidingsafdeling nieuwe cursussen te ontwikkelen.

De trainer. De trainer heeft in deze opzet ook een nieuwe rol te spelen. Hij of zij werkt nauw samen met de regionale specialisten en de coördinator bij het opzetten en begeleiden van cursussen. De opleidingsfunctie is veranderd van een vrij afstandelijke scholingsafdeling naar een directe professionele ondersteuning van de specialistenclusters en de regionale teams. Het is een schakel geworden in de kenniscyclus.

Het management team heeft de taak richting te geven aan de ontwikkeling van nieuwe cycli en is verantwoordelijk voor de borging van de kennis.

De introductie van deze nieuwe methodiek van kennisontwikkeling en kennisborging kan op de eerste plaats gezien worden als een directe consequentie van de gekozen nieuwe, meer slagvaardige organisatievorm. Kennis en ervaring mag niet weglekken en moet effectief ter beschikking worden gesteld van de regionale medewerkers. Deze werkwijze introduceert echter bovendien een nieuw element in het management van Nationale Nederlanden. Het belang van de beheersing van kennisstromen wordt expliciet als een nieuwe functie in het bedrijf gezien. In deze visie wordt de ontwikkeling en de overdracht van kennis niet beschouwd als een optelsom van specialistische capaciteit en adequate training. Kennismanagement betreft de voortdurende stroom van zinvolle informatie door het hele bedrijf. Een stroom die mensen samenbindt in hun streven om de klant beter te bedienen.

\section{Strategisch personeelsbeleid}

Personeelsbeleid is lang opgevat en gepraktiseerd als een operatie, als een beheersfunctie. De uitvoering van het personeelsbeleid werd ondergebracht in een aparte staffunctie met als hoofdtaak ervoor te zorgen dat de vragen uit het bedrijf effectief werden beantwoord: het vullen van opengevallen plaatsen, het bij- en omscholen, overplaatsingen, training en opleiding, en beloning. De toegenomen kennisintensiteit van bedrijven vraagt echter om meer dan een operationele inzet van het personeelsbeleid. De medewerkers van de onderneming vormen immers de belangrijkste ontwikkelaars, dragers en gebruikers van kennis. De uitdaging voor het personeelsbeleid is om de kennishuishouding binnen het bedrijf en de kennisuitwisseling met de omgeving te versterken. De vijf voorbeelden in deze studie laten zien welke patronen bedrijven die HRM ernstig nemen hebben ontwikkeld. Opmerkelijk is dat deze patronen voor een belangrijk deel gebaseerd zijn op de bekende instrumenten van het personeelsbeleid en het organisatiebeleid. De instrumenten zijn niet nieuw, maar wel de wijze waarop zij worden ingezet: ter ondersteuning van de bedrijfsontwikkeling. In deze patronen zijn een zestal basiselementen te onderkennen.

\section{Kennismanagement is gerelateerd aan de bedrijfsontwikkeling}

De meeste bedrijven beginnen ervan doordrongen te raken dat zij zich in het kennismanagement moeten concentreren op kerncompetenties. Dat zijn de kennis en vaardigheden die men weerspiegeld vindt in de kerntechnologie van het bedrijf en die op de markt de basis vormen voor het competitief voordeel van de onderneming. Bij de formulering en uitvoering van het personeelsbeleid stelt men zich voortdurend de vraag wat de toegevoegde waarde is van beleid en beslissingen aan de versterking van de kerncompetenties. De bedrijven die hier ten tonele zijn gevoerd, richten zich niet alleen op de huidige kerncompetenties. Zij proberen ook de wenselijk geachte toekomstige kerncompetenties in concrete maatregelen te vertalen. Uitgangspunt is een duidelijke strategische missie die door de top wordt onderschreven en die bij voortduring wordt uitgedragen. Het management van kennisstromen wordt in deze ontwikkeling met name relevant bij het streven naar een grotere marktgerichtheid van de organisatie. De 
opgave is daarbij tweeledig: zowel het doorbreken van de kunstmatige grenzen tussen functionele afdelingen als de borging van functionele kennis.

Kennismanagement begint bij de werving en selectie

Werving en selectie is bij elk van de bedrijven een belangrijke schakel in het kennismanagement. Men is niet alleen geïnteresseerd in het vullen van opengevallen posities en het aantrekken van mensen met een grote vakkennis. In de selectie is de toekomst al aan de orde. De kennis en vaardigheden die men zich nog eigen moet maken zijn minstens van even groot belang als de gegevens van vandaag: de kenmerken van de huidige functie en de huidige capaciteiten van de kandidaat.

Personeelsontwikkeling is een management-verantwoordelijkheid

In elk van de vijf bedrijven werkt men met een methodiek voor de begeleiding van personeelsontwikkeling. Personeelsontwikkeling wordt gestuurd. Dat betekent dat met grote regelmaat met de medewerkers gesprekken worden gehouden waarin de ontwikkeling van het individu wordt afgezet tegen de ontwikkeling van de onderneming. Bij de inzet van personeel in nieuwe projecten wordt niet alleen rekening gehouden met de kennis en ervaring waarover zij al beschikken, maar ook met die kennis en ervaring die zij nog op moeten doen. Dat proces wordt geformaliseerd zodat het gepland, gevolgd en bijgestuurd kan worden. Personeelsmanagement draagt de instrumenten aan, maar de verantwoordelijkheid ligt bij het lijnmanagement. Het belang van het personeelsmanagement neemt toe wanneer er bruggen geslagen moeten worden over de grenzen van kennisdomeinen heen. De personeelsontwikkeling heeft bovendien duidelijk betrekking op het "personeelsonderhoud". Voortdurend dient ervoor gewaakt te worden dat de kennis en vaardigheden van medewerkers door de intensieve inzet in projecten niet verslijten. Instrumenten daarvoor zijn: stages, deelname aan vakontwikkelingsprojecten, opleidingen en sabbaticals en tijdelijke detacheringen in corporate ontwikkelingscentra.

De koppeling van ontwikkeling en opleidingen

Met name in de dienstverlenende bedrijven in deze studie wordt een directe verbinding gelegd tussen de ontwikkelfunctie en de opleidingsfunctie. Het mes snijdt hier aan twee kanten. Aan de ene kant kan hierdoor een nieuw produkt of een nieuwe dienst zo snel mogelijk op de markt worden gezet. De kennis die in het bedrijf wordt ontwikkeld moet immers kunnen worden overgedragen op de klant. De medewerkers zijn hierbij het belangrijkste voertuig. Aan de andere kant wordt een directe bijdrage geleverd aan de personeelsontwikkeling. De medewerkers worden direct en voortdurend gevoed met nieuwe kennis die in het eigen bedrijf is opgedaan. Deze trend zal voor de industriële bedrijven in de komende jaren steeds meer aan relevantie winnen, doordat zij zich in toenemende mate ontwikkelen van producenten naar dienstverleners.

\section{De introductie van laterale verbanden}

Kennisstromen doorsnijden meestal bestaande of juist recent ingevoerde organisatorische grenzen. De grenzen tussen de corporate organisatie en de business units, de grenzen tussen business units en functionele afdelingen onderling. Hiërarchische kanalen raken snel verstopt en zijn slechts beperkt bruikbaar voor de geleiding van kennis. Laterale groepen (Galbraith, 1994) bewijzen hier hun nut. Zij doorsnijden bestaande organisatorische grenzen zonder de hiërarchie hierbij te belasten. De "kennisclusters" bij Nationale Nederlanden en de "dwarsverbanden" bij Océ zijn hiervan goede voorbeelden. Deze laterale verbanden hangen niet als vage commissies in de lucht, maar maken deel uit van een kennisstructuur waarin doeleinden, verantwoordelijkheden vastliggen en waarin het management zorg draagt voor de borging.

\section{Kennissystemen}

Bij het kennismanagement in de bedrijven in deze studie vervulde de informatietechnologie een belangrijke ondersteunende rol. Men denke aan de simulatiesystemen van Pink Elephant, het R\&D-netwerk van Océ, en de kennisbank van NN. Informatietechnologie is relevant voor elk facet van de kenishuishouding. Opmerkelijk is echter dat de bedrijven de informatietechnologie primair vanuit de bedrijfsontwikkeling en de competentie-ontwikkeling benaderen. $\mathrm{Zij}$ gaan niet uit van abstracte blauwdrukken van het bedrijf als kennissysteem. Het "machinedenken", waarin voortdurend en systematisch de latente ("zwijgende kennis", of "tacit 
knowledge") kennis wordt afgetapt en in algoritmes wordt gegoten is hen vreemd. De opbouw, onderhoud en overdracht van kennis staat centraal. De actoren in dat proces wordt met de informatietechnologie instrumenten aangereikt om hun taak efficiënter te kunnen vervullen. De instrumenten worden niet volgeladen met menselijke kennis. Het is andersom: de mens als kennisverwerker wordt voorzien van effectieve instrumenten. Een goede illustratie vormt de invoering van kennissystemen bij NN. De tussenpersonen krijgen kennissystemen waarmee standaardpolissen kunnen worden verwerkt. Daardoor ontstaat binnen de regionale teams ruimte om meer aandacht aan de dienstverlening te geven. Het technische systeem schept ruimte voor kennisontwikkeling en kennisoverdracht in plaats van die te annexeren.

\section{Het ontwerp van een kennisstructuur}

Bij de introductie van management van kennisstromen is in de meeste bedrijven sprake van een duidelijke systematiek. Het kennismanagement ontleent haar kracht aan de gemeenschappelijke structuur waarin de delen goed op elkaar passen. Er zijn echter verschillende wegen waarlangs een dergelijke structuur bereikt kan worden. Er zijn bedrijven die zich wel bewust zijn van de noodzaak aan sturing van kennisstromen, maar die vooral geloven in kleine (incrementele) stappen zonder een duidelijke regie. Men neemt achtereenvolgens op tal van terreinen initiatieven, zonder dat die initiatieven op elkaar aansluiten. Er worden bijvoorbeeld kennissystemen ingevoerd zonder dat die in een kennisstroom passen. Of er wordt op corporate niveau een "technology council" ingesteld zonder instrumenten om de kennisstromen gericht te beïnvloeden.

De bedrijven in deze studie hebben niet voor deze weg gekozen omdat deze leidt tot het "opknippen" van de kennisstromen in kleine brokken en niet tot een "stroomversnelling". Bedrijven als MEY en Pink Elephant hebben wel een stapsgewijze ontwikkeling doorgemaakt, maar zijn daarbij wel uitgegaan van een bindende visie en een duidelijke ontwikkelingsrichting. Men streeft ernaar vanuit bestaande functies (opleidingen, de inzet van informatietechnologie, loopbaanbegeleiding) een samenhangend en intern zich versterkend geheel te maken. De rol van opleidingen komt dan bijvoorbeeld tot zijn recht door een directe koppeling met de produktontwikkeling (MEY, Pink Elephant, NN) en loopbaanbegeleiding. In bestuurskundig lingo noemt men een dergelijke benadering "mixed scanning": stapsgewijs naar een helder verderliggend doel. Bij NN heeft men wel voor een "radicale" aanpak gekozen. Er is een compleet herontwerp van de kennisstroom gemaakt en de structuur is in één keer neergezet. Deze structuur moet zich nog verder ontwikkelen, maar de nieuwe samenhangen tussen functies zijn direct duidelijk neergezet. Deze aanpak ligt bij NN voor de hand omdat daar in een vrij korte periode is overgegaan tot een fundamentele verandering in de organisatie met een direct risico voor het weglekken van kennis. In een dergelijke situatie is een zeer systematische werkwijze bij het ontwerp van de kennisstructuur onontkoombaar.

Bij het ontwerp van de kennisstructuur zijn de volgende hoofdfasen te onderkennen:

\section{Functionele eisen}

De functionele eisen waaraan een kennishuishouding moet voldoen zijn een afgeleide van de strategische doelen die de organisatie zich stelt. Voor Raychem is het duidelijk dat drie eisen het zwaarste wegen: (1) het absorberen van state-of-the-art-technologie uit een verzameling van disciplines, (2) het combineren van die technologieën in produktfamilies, en (3) het vasthouden en verspreiden van toepassingskennis die in de markt wordt opgedaan. In dit bedrijf beperkt men zich niet tot de dag van vandaag: er wordt ook voortdurend nagegaan welke eisen in de toekomst aan de kennishuishouding worden gesteld.

\section{De identificatie van kennisvelden}

Op welke kennisgebieden moet het bedrijf zich onderscheiden van de concurrentie en welke kennis moet het bedrijf ten minste in huis hebben om het bedrijf draaiende te houden? Die vragen komen in de tweede fase aan de orde. Hier zullen keuzes gedaan moeten worden omdat een bedrijf beperkte mogelijkheden heeft. Bovendien kan kennis niet uit de grond worden gestampt. De kennis die men in de toekomst wil ontwikkelen is in belangrijke mate afhankelijk 
van de kennis die men nu al heeft (Den Hertog et al., 1991) Vooral bij zeer kennisintensieve bedrijven (zoals in de chemie, farmacie, electronica, automatisering en accountancy) is de acquisitie vaak de enige weg om binnen overzichtelijke termijnen de kennisbasis fundamenteel te veranderen.

Bij de kennisvelden is niet alleen de kennis aan de orde die binnen de R\&D-afdelingen en universiteiten wordt ontwikkeld. De kennisvelden betreffen de hele bedrijfsketen: van marktkennis, proceskennis, toepassingskennis en distributiekennis.

3. De analyse van de bestaande kennisstromen en het aangeven van bottlenecks en "lekkages"

Waar wordt de kennis in het bedrijf ontwikkeld of binnengehaald, waar wordt zij verwerkt en waar gebruikt? De beantwoording van deze vragen levert een ruwe kaart van bestaande kennisstromen. Op die "kaart" kunnen ook de knelpunten en de lekkages worden aangegeven. Zo kan men vaststellen dat de marketeers nauwelijks inzicht hebben in de produkten die er aan komen en dat bij een overgang op een regionale organisatie (vergelijk NN), produktkennis dreigt verloren te gaan.

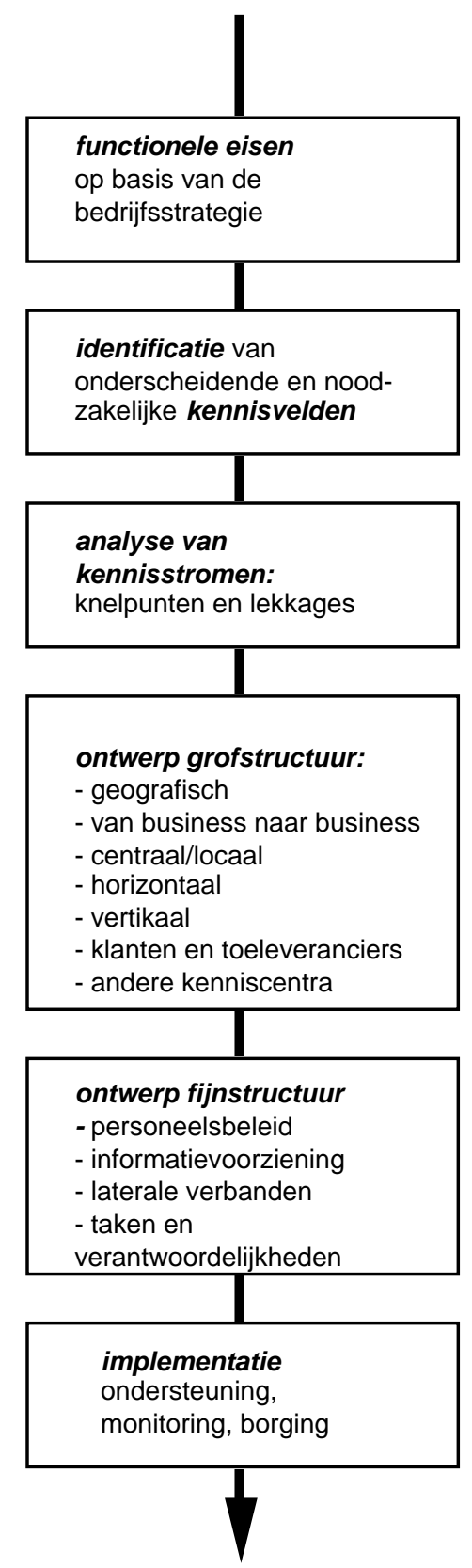

Figuur 3: Het ontwerp van de kennisstructuur 


\section{De opbouw van de grofstructuur}

In de grofstructuur worden voor de verschillende kennisvelden de wenselijk geachte kennisstromen aangegeven. Bij die kennisstromen zijn de volgende hoofddimensies te onderscheiden:

- de stromen tussen geografisch gespreide eenheden (regio's)

- de stromen tussen business units

- de vertikale stroom van functionele kennisgebieden naar de project-organisatie

- de horizontale stroom in de projectorganisatie, dwars door functionele gebieden

- de stroom tussen de corporate organisatie en de business units

- de stromen van klanten en toeleveranciers naar de horizontale project-organisatie

- de stromen die andere kennisleveranciers (bijvoorbeeld universiteiten) met het bedrijf verbinden.

In de nieuwe kennisstructuur wordt aangegeven waar sprake zal moeten zijn van een stroomversnelling. Het bedrijf kan er ook voor kiezen zich terug te trekken van bepaalde kennisgebieden om de aandacht beter op andere te kunnen richten.

\section{Instrumentatie}

Men zou ook kunnen spreken van het ontwerp van de "fijnstructuur". Hier wordt een keuze gemaakt uit te gebruiken methoden en instrumenten op drie hoofdterreinen:

Personeelsbeleid: werving, selectie, loopbaanbegeleiding, opleidingen, en beloningssystemen die kennisontwikkeling en -overdracht stimuleren.

Laterale groepen: de invoering van kennisclusters waarin business units, regionale eenheden en corporate ontwikkelgroepen participeren (zie Galbraith, 1994). De NN-case geeft hier een voorbeeld van.

Informatievoorziening: informatietechnologie kan op verschillende manieren worden ingezet om de kennisstructuur te versterken: een informatie-infrastructuur die een snelle communicatie mogelijk maakt, kennissystemen waarin uitgekristalliseerde kennis verpakt wordt en beschikbaar wordt gesteld, en gegevensbanken die gemeenschappelijk binnen het bedrijf kunnen worden aangewend.

In het ontwerp van de "fijnstructuur" worden taken en verantwoordelijkheden voor de kennishuishouding vastgelegd: de borging, de coördinatie, infrastructuur (laterale groepen), en de ondersteuning (IT en opleidingen).

\section{Implementatie}

Het is duidelijk dat de implementatie zelfs bij een duidelijke kennisstructuur en instrumentatie veel aandacht zal vragen. De structuur is aangegeven als in een boekenkast, maar de schappen moeten nog worden gevuld. Bovendien zullen de leden van de organisatie nog moeten leren hoe zij met de nieuwe systematiek moeten omgaan. Men zou kunnen zeggen dat een kennisstructuur niet wordt "ingevoerd", maar wordt ontwikkeld.

\section{Tot slot}

In de laatste vijf jaar hebben veel bedrijven de bakens grondig verzet. Het complex van veranderingen kan misschien het beste worden weergegeven met het woord "stroomlijning" (Philips et al., 1994). Dat is een proces van debureaucratisering en decentralisering, waarin de functies van de onderneming hechter op bedrijfsprocessen worden gebonden. De business unit is een exponent van die ontwikkeling. Evenzeer de afbouw van de corporate organisatie en de integratie van produktiebedrijven binnen ondernemingen. Stroomlijning maakt het mogelijk om sneller op ontwikkelingen in de markt te reageren en om de kosten te drukken. Veel bedrijven zijn dezelfde weg ingeslagen. De vraag die in de komende jaren steeds sterker naar voren zal komen, is hoe men zich in een dergelijke ontwikkeling van elkaar kan blijven onderscheiden, wanneer bijna elk bedrijf even flexibel, marktgericht en kwaliteitsbewust is geworden. In dit 
paper wordt het antwoord gezocht in het ontwikkelen en aanwenden van kennis die niet van vandaag op morgen door afkijken of inkopen kan worden verworven. Dat betekent geen teruggang naar zware functionele en centraal opgestelde kenniscentra, maar investeren in de kennisstromen dwars door de binnen- en buitengrenzen van de onderneming. Human Resources Management krijgt daarmee een concrete invulling.

\section{Bronnen}

Assen, A. van, 1990, Technologie en personeelbeleid: De draad van Ariadne in het technische labyrint, inaugural speech. Nijmegen: University of Nijmegen.

Bohn, R.E. (1994). Measuring and managing technological knowledge. Sloan Management Review, vol. , no.3, 61-73.

Cobbenhagen, J., Hertog, J.F. den and Pennings, J.H. (1994). Succesvol veranderen: Kerncompetenties in bedrijfsvernieuwing. Deventer: Kluwer.

Coriat, B. (1995). Organisational innovations: The missing link in European competitiveness. In: L. E. Andreasen, B. Coriat, J.F. den Hertog and R. Kaplinsky (eds.) Europe's next step: Organisational innovation, competition and employment. London: Cass Publishers.

Cooper, R.G. (1994). Third generation new product processes. The Journal of Product Innovation Management. Vol. 11, no. 1, 3-15.

Davis, S. and Botkin, J. (1994). The coming of knowledge-based business. Harvard Business Review, vol. 73, no.5, 165-170.

Diepen, B. van (1995). Engineers, project to project-routes and RED effectiveness: Effects of different career tracks. Maastricht: MERIT/Rijksuniversiteit Limburg, forthcoming.

Galbraith, J.R. (1994) Competing with flexible lateral organizations (2nd ed,) Reading, MA: Addison-Wesley.

Florida, R. and Kenney, M. (1990). The breakthrough illusion: Corporate America's failure to move from innovation to mass production. New York: Basic Books.

Hertog, J.F. den, Sluijs, E. van, Assen, A. van and Diepen, B. van (1991). Innovatie en personeelsbeleid. Bedrijfskunde, vol. 63, no. 2, 158-168.

Hertog, J.F. den (1995). Enterpreneurship on the shop floor: Nationale Nederlanden. In: L. E. Andreasen, B. Coriat, J.F. den Hertog and R. Kaplinsky (eds.) Europe's next step: Organisational innovation, competition and employment. London: Cass Publishers.

Hippel, E. von (1986) Lead users, A source of novel product concepts. Management Science, vol. 32, no. 7.

Nonaka, I. (1991). The knowledge-creating company. Harvard Business Review, vol. 70, no. 6, 96-104.

Nonaka, I. (1994). A dynamic theory of organizational knowledge creations. Organization Science. Vol. 5, no.1, 14-38.

Prahalad, and Hamel, G. (1990). The core competences of the corporation. Harvard Business Review, vol. 68 , no. 3, 79-91.

Rothwell, R. (1992). Successful industrial innovation: Critical factors for the 1990s. RED Management, vol. 22, no.3, 221-239.

Sluijs, E. van, A. van Assen and J.F. den Hertog, 1991, Personnel management and organisational change: A sociotechnical perspective, European Work and Organizational Psychologist, Vol. 1, no. 1, pp. 27-51.

Sluijs, E. van and J.F. den Hertog, 1993, Praktijkverkenning personeelwetenschappen. Tilburg: University of Brabant.

Takeuchi, H. \& Nonaka, I. (1986). The new new product development game. Harvard Business Review, vol. 64, no. 1, 137-146.

Ven, A.H. van de (1986). Central problems in the management of innovation. Management Science, vol. 32 , no. 5, 590-607. 